\title{
Monopoly: The Case Of Egyptian Steel
}

Tarek H. Selim, (E-mail: tselim@aucegypt.edu), American university in Cairo, Egypt

\begin{abstract}
The local steel industry in Egypt has been protected by high tariffs which were relaxed lately. The market is segmented according to steel type and there is a dominant steel producer acting as a monopoly in the market. Due to barriers to entry in the short run and the dominant market position of the monopoly, price elasticity became more demand inelastic. However, the dominant market player carries an innovative edge over its competitors.
\end{abstract}

\section{INTRODUCTION}

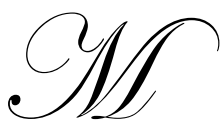

arkets behave according to rational economic incentives and policies. The Egyptian steel industry is an interesting case to analyze because it is a strategic source of raw material for other industries (such as construction) and comprises a large portion of Egyptian industrial GDP. It is characterized by market segmentation, a dominant market position, and efficiency elements. There is, however, an interesting tradeoff between market monopoly and market efficiency as the local industry is constrained by barriers to entry and international factors. Short run and long run implications of this case are of crucial importance to economic analysts and decision makers alike.

\section{INTERNATIONAL MARKET}

Steel is largely dependent on three big end users: construction, packaging and car manufacturing. China is the world's largest crude steel producer (2003) with around 220 million tons of steel production comprising $23 \%$ of world production, the latter estimated as 960 million metric tons. The EU headed by Germany is the second world's largest steel producer with 159 million tons of crude steel (18\% of world production in 2002), and then comes Japan and USA. On the other hand, USA is the largest importer of steel products (2002) followed by China and Germany. The world's largest exporter of steel is Japan (2002), followed by Russia and Ukraine. China has seen the highest growth rate in steel production, whereas the European Union (15 member countries) and the USA have shown no considerable growth during that time. However, for every year since 1990, the EU produces systematically larger amounts of steel than Japan, while Japan in turn produces systematically larger amounts of steel compared to the United States.

On the other hand, a promising country in future steel production is India. Indian steel mills are starting to expand their capacity to meet the expected growth in internal demand. Foreign steel companies are starting to make investments for steel manufacturing in India to build plants using the available local sources of raw material. "Mital" is an Indian company that is emerging now in the international steel industry.

In 2003, 970 million tons of crude steel have been consumed worldwide compared with 915 million tons in 2002 resulting in a consumption growth rate of the industry of 6.9\%. On the global production side, 960 million tons were produced in 2003 compared with 883 million tons in 2002 resulting in a production growth rate of the industry of $8.7 \%$. China is the largest consumer of steel consuming 258.2 million tons while USA consumes about 103.9 million tons. 


\section{Cost In The International Market}

Due to the rapid growth in the Chinese steel industry becoming the world's largest in a short period of time, and the switch from local iron ore to imported iron ore, there were increases in the cost of raw materials. The requirements of the Chinese, particularly for iron ore, were driving up prices, giving rise to some shortages and driving up the freight costs associated with moving bulk goods like iron ore.

Delivered prices for raw materials had risen very dramatically on world markets, and the steel industry was faced with a structural shift in the price of making steel. Steel prices rose on average by about 50\% in 2004 and some expect that it will continue to increase. From here, we can consider that the current international market for steel is at disequilibrium because there is high demand from China for the iron ore. So demand for raw materials of steel exceeds the supply, which drives market prices above the equilibrium price.

\section{LOCAL STEEL MARKET}

The Egyptian steel sector relies heavily on rebars that account for around $80 \%$ of all steel sales in Egypt. For production of rebar, steel billets are used as raw materials. Currently local billet production in Egypt is not sufficient to meet the demand of rebar manufacturers as the iron ore in Egypt has a 53\% concentration of iron while the industry needs at least 73\% concentration of iron. Around 1.2 million tons of steel billets are imported each year to Egypt. The local market for steel is segmented according to type of steel. In general, the types of steel produced in the Egyptian market consist of:

- $\quad$ Carbon steel: includes long and flat steel. The long steel consists of many types, the most important are reinforced bars, spring flat bars and bulb flats. The flat steel consists of coils and sheets. There are also other types of carbon steel such as chains, welding wires and forgings.

- $\quad$ Stainless steel: includes also long and flat steel. The long steel consists of bright shafting bars, tubes and pipes. The flat steel consists of coils and sheets that may be decorative and etched.

- $\quad$ Special steel: includes alloy steel, bimetal, heat resistant steel, steel fibers, high-speed steel and mould and tool speed.

\section{Supply In The Local Market}

During the early nineties, private sector investors started investing in the rolling mills to end the government control of steel production capacities in Egypt. Production capacities adopted an increasing trend in the mid-nineties to cope with the increase in demand for steel rebar.

The Egyptian steel sector today is dominated by Ezz Steel Rebars (ESR) who acquired a 28 percent share of government controlled Alexandria National Iron and Steel Company in Dikhela (ANSDK). The two companies consolidated their marketing operations under the name Ezz-Dekhela Steel (EZDK), of which Ahmed Ezz was appointed chairman in March 2000. The marketing alliance of ESR and EZDK also goes by the name Ezz-Dekhela (EZDK). EZDK has maintained a dominant position, and the company now controls around 54 percent of the total market potential capacity and 61 percent of the market share. EZDK's objective is to maintain its dominance over the Egyptian steel market share by holding on to its increasing market share.

There are other private producers such as Kouta Steel Group, Suez Steel, Beshai Steel, Aswan for Iron, and the Arab Steel Factory, which account for around 26 percent of the market. Public sector companies such as Helwan Steel make up about 7 percent of the market. Thus, it is obvious that the steel sector is dominated by private business with weak competition from the public sector.

Table 1 below is a list of market shares in the Egyptian steel industry. The Hirschman-Herfindahl Index (HHI) for market concentration in the Egyptian steel industry is calculated accordingly as 3,822. It is worth mentioning that a perfectly competitive market has a zero HHI index while a complete monopoly an HHI of 10,000. The monopolistic performance of the entire industry, therefore, is in excess of a one third dominant monopoly power 
in terms of market share distribution for the entire spectrum of firms in the industry. On the other hand, specific concentration ratios reveal a more dominant monopoly power of the Ezz Dekhela partnership. The two-firm and threefirm concentration ratios are $60.7 \%$ and $69.3 \%$ respectively. This implies there is a very strong and excessively dominant monopoly power for the merged duopoly partnership (Ezz Dekhela) and that such an excessive monopoly power is seven times as strong as its next best challenger.

Table 1: Market Share Of Local Steel Rebar Producers, 2000

\begin{tabular}{|l|c|c|}
\hline \multicolumn{1}{|c|}{ Supplier } & Production (million tons) & Market Share \\
\hline Ezz Steel & 1147 & $27.5 \%$ \\
\hline Alexandria National Iron and Steel & 1375 & $\mathbf{6 0 . 7 \%}$ \\
\hline Ezz-Dekhela & $\mathbf{2 5 2 2}$ & $8.6 \%$ \\
\hline Kouta Group & 360 & $6.6 \%$ \\
\hline Int'l St. R.M.-Beshai & 275 & $2.2 \%$ \\
\hline Delta Steel & 91.8 & $2.0 \%$ \\
\hline Suez Co. Al-Koumy & 82 & $1.9 \%$ \\
\hline Egyptian Metal Hatem & 80 & $1.3 \%$ \\
\hline Egyptian Iron\& Steel & 56.2 & $1.2 \%$ \\
\hline Al-Said Steel & 50 & $1.1 \%$ \\
\hline Menouefya Steel & 46 & $0.9 \%$ \\
\hline Ayyad Rolling & 36 & $0.8 \%$ \\
\hline Egyptian Copper Wk & 34.2 & $0.8 \%$ \\
\hline Al-Arabi Planet Sharkawi & 33 & $0.6 \%$ \\
\hline Misr Iron \& Steel & 24 & $0.6 \%$ \\
\hline Al-Temsah Steel & 24 & $0.4 \%$ \\
\hline National Metal Ind. & 16.9 & $<0.1 \%$ \\
\hline Sarhan Steel & $<3.7$ & $89.7 \%$ \\
\hline Total & 3731 & $10.3 \%$ \\
\hline Imports & 440 & \\
\hline
\end{tabular}

The Egyptian steel sector relies heavily on rebar, which account for around four fifths of all steel sales in Egypt. Because this type of steel is used mainly in construction projects, the recession and accompanying downturn in the real estate market has resulted in weak demand. The drop in demand in 2000 and 2002 coupled with the continuous increase in production capacities to reach 6.4 million tons in 2002 versus 5.6 million tons in 2001 resulted in a supply-demand gap. The gap created intensified competition in the steel market creating price wars between major steel producers.

Most of the steel companies import raw materials to satisfy their production requirements as the iron ore in Egypt has a lower concentration ratio than industrial requirements as mentioned above. As the cost of raw materials is increasing in an upward trend, producer's profit margins are decreasing.

Only EZDK, which runs fully integrated plants, has serious international certification of its products. In 2003, EZDK produced 3.5 million tons and exported 0.85 million tons and he is considered the largest steel exporter among the Arab nations. "Ezz has the best quality" was the common answer among the engineers and steel workers that we have interviewed.

Steel industrial plants are concentrated in Suez Industrial zone, Sadat City, and $6^{\text {th }}$ of October industrial zone. Producer's externalities consist of the limestone and iron ore impurities collected at the top of the molten iron, which make up the largest portion of iron making byproducts. They are resold to the construction industry. Blast furnace flue gas is also generated during iron making. This gas is cleaned to remove particulates and other compounds, allowing it to be reused as heat for coke furnaces or other processes. The dust can be reused in bricks, cement, sandblasting or fertilizers. 


\section{A SCENARIO OVER MONOPOLY}

The steel industry in Egypt is accused of being a monopoly especially that the market supply of steel has an inelastic price behavior in the short run. There have been many accusations directed to Ahmed Ezz for exerting a monopoly over the steel market thus distorting the price. The past few years, the government imposed high tariffs on the importation of steel, which was $20 \%$ to protect the domestic industry. Having done that, the consumers of steel found themselves forced to buy from Ezz. However, due to the objections of many people in the media for this monopoly situation, the government found himself forced to decrease the tariffs imposed on steel form $20 \%$ to $5 \%$. But because recently the prices of steel worldwide has risen tremendously due to the appearance of China as a major player, it is not beneficial anymore to import steel form abroad. So the monopoly still persists.

In an interview with Dr. Samir Makary who has a good experience with the steel industry, there was another scenario that appeared on the scene. "I do not consider Ezz a monopoly, I can rather call it an oligopoly" said Dr. Makary. "Actually there are two types of oligopolies: the first one is when the dominant market producers agree together on the price. The second one is when there is a dominant producer such as Ezz and there are also other powerful producers such as Kouta, Beshai and Portsaid" added Dr. Makary. When he was asked about why Ezz is then considered a monopoly he replied "Ezz puts high prices on his products because he has to do this. In other words, the prices of steel worldwide are highly fluctuating and the cost of producing steel in Egypt is very high because Egypt does not have a comparative advantage in the production of steel as our steel has residuals, i.e. it's a low quality. Also, because the cost of mining and extracting steel is also very high in Egypt because we do not have the (required) technology and funds for extracting steel from the core of the earth. As a result, Ezz had to put high prices on his products in order to make profit in contrast to the other countries such as Ukraine who already have low cost in the production of steel so they always make profits even when charging lower comparative prices". We asked Dr. Makary "but why did many steel firms shut down? " He replied, "the steel industry is a risky business because of price fluctuations, and it also requires a lot of capital invested. In addition, the rebar require billets to be produced and these billets have to be imported from abroad at high prices. However Ezz is the only one who produces billets in Egypt so he does not incur the high costs of importing it like the other firms do." He was then asked: "But why other firms do not produce billets in Egypt too like Ezz?". He replied: "Because the cost of making billets is very high and risky and Ezz has the enough funds and capital to incur these cost and also he has a political power in addition to his acquirement of the El Dekhela Plant, so other firms cannot blame Ezz for having the required funds while they do not have it".

\section{GOVERNMENT REGULATIONS}

Four main decisions were taken by the government in 2003 to avoid any monopolistic actions that might occur in the steel market:

1. Reducing custom duties (tariffs) on imported steel to 5\% down from $20 \%$.

2. Totally exempting scrap used in the rebars and flat steel production process from all tariffs and maintaining the billets tariffs at $3 \%$.

3. Eliminating all "anti-dumping duties "imposed on Egypt's imports from certain countries.

4. The establishment of a new billet production plant with a total capacity of 1 million tons per annum in order to reduce the dependence on important billets.

However, on the other hand, one of the major drawbacks of the Egyptian government that hinders progress is routine and bureaucracy. As stated by Mr. Magdy Fahmy, some furnaces have been ready for production for months but did not operate yet because of the delayed allowance of electric and water supplies from the government.

\section{Barriers to Entry}

There are several entry barriers to the steel industry in Egypt. Firstly, quality steel production requires sizeable capital. Secondly, local capacity exceeded consumption since 2000. Moreover, the fact that the new merger makes a single company control $61 \%$ of the total local market seriously discourages new players from attempting to 
enter the market (EFGH-Hermes, 2001). Steel prices normally have a tendency to be fairly elastic. However, the new merged company with over $60 \%$ market share, combined with the fact that the company is a quality steel producer, has made the market more price inelastic particularly in the short term. Ezz's competitive edge gives it considerable flexibility when setting prices. The difference in price between the steel produced by the merged firm and the other market players reach $10 \%$ with the merged firm prices normally at the higher end of the market.

\section{Demand Side}

The demand for steel in Egypt is mainly dependant on fabrication and construction in addition to some other steel users like air conditioning, needles, furniture, elevators, agricultural equipments, electric cable and equipments, motor and other industries that use steel as a raw material. As for fabrication and construction, the major consumers of steel are Arab Contractors, Orascom Construction industries, Egyptian Contracting, and Industrial and Engineering Products Company. Negative consumer externalities consist of the gaseous emissions and metal dusts as the most prominent sources of waste from electric furnaces. Sulfur dioxide and hydrogen sulfide are volatized and captured in air emissions and cause acid rain if the emission control equipments are not used efficiently. These emissions cause respiratory problems and water pollution which evidently affects the quality of drinking water and fishery.

Steel is a necessity for different sectors of the Egyptian economy, such as construction. Moreover, it is capital intensive and has an inelastic demand. However, in our case when steel prices increased in 2003 many average construction-owners paused its operation, as they couldn't buy the steel at that price. Thus the inelasticity dimension of the market has caused opportunity losses in the economy.

\section{Construction and Cement Sectors}

The construction sector is the major user of steel. Rebars and other steel products account for 30 percent of construction and $10 \%$ to $25 \%$ of building costs in Egypt. As construction in many countries rely on wood and other fabrics like in USA, this is not the case in Egypt as the expansion here is vertical not horizontal. Thus, in Egypt, a contractor has to build many stories in one building (vertical) in order to surpass break-even levels and obtain profits as the contractor Emad Shafee stated, while in other countries such as USA you can build a short building and expand horizontally and still profit from it.

\section{Factor Inputs}

\section{Raw Materials Inputs}

Steel is an alloy of iron and carbon, containing less than $2 \%$ carbon, $1 \%$ manganese and small amounts of silicon, phosphorus, sulphur and oxygen. Steel is the most important engineering and construction material in the world. It is the most important, multi-functional and most adaptable of materials. Steel compared to other materials of its type has low energy production costs. The energy required for extracting iron from its ore is about $25 \%$ of what is needed for extracting aluminum.

There are altogether about 2,000 grades of steel developed of which 1,500 grades are high-grade steels. The large number of grades gives steel the characteristic of a basic production material. Steel can be cast into bars, strips, sheets, nails, spikes, wire, rods or pipes as needed by the intended user.

Steel production at an integrated steel plant involves three basic steps. First, the heat source used to melt iron ore is produced. Next,. the iron ore is melted in a furnace. Finally, the molten iron is processed to produce steel. These three steps can be done at one facility; however, the fuel source is often purchased from off-site producers. Coke is used in the production of iron steel. During iron making, iron ore, coke, heated air and limestone or other fluxes are fed into a blast furnace. 


\section{Cost Of Raw Materials}

In an interview with Karim Ayesh, the owner of International Steel Products Supply, which is an importer of billets, he mentioned that he imports billets from Ukraine and Turkey. They supply all their imports to only one big steel firm that is called "The National Company for Steel, or Portsaid". Mr. Ayesh said that the prices of steel worldwide are extremely fluctuating, and this could lead to many losses for their company. "Steel, is a risky business" said Mr. Ayesh.

Concerning the cost of billets, there are some tactics that are used in the industry. Suppose that the price for billets in the international market is indexed at 320, a wholesaler of steel billets can make a deal with a foreign supplier, such as from Ukraine, and strike a business deal for an indexed price of 310 on condition that they take large enough amounts. After this, the local steel wholesaler can sell those billets to the steel firms in Egypt for an indexed price of 315 . In this case, the local industry gets an advantage, by offering a lower price to the local steel firms compared to the international price and at the same time local steel wholesalers can make sizeable profits.

\section{Capital And Labor}

The steel industry is mainly capital-intensive. This by itself is a natural barrier to entry in Egypt. However, it cannot be said that the steel industry depends on capital alone. There is some degree of complimentarily between labor and capital. Due to the complexity of the machinery and tools used in the production process, skilled and experienced labor, such as professional engineers, are required and thus act as cost overheads to the industry. Supervision is crucial to ensure that everything in the production process goes according to the technical plan.

\section{SWOT Analysis}

Strengths

The steel industry in Egypt represents an important aspect to the economy. It represents $19.2 \%$ of the industrial GDP (2002). The production of steel in Egypt depends heavily on rebar that is an important input to the construction industry in Egypt.

\section{Weaknesses}

The Egyptian market for steel is considered a monopoly since Ezz-Dekhela represents a dominant market share of $61 \%$ while creating a price distortion of at least $10 \%$ in the short run. Long run quantity distortions are incalculable at the present time. However, if other steel firms get the opportunities to enter the market by removing entry barriers and facilitating funding of capital, the prices will adjust and the market will operate at equilibrium. On the other hand, it is important to identify Ezz-Dekhela has the most innovative firm in the industry.

\section{Opportunities}

Due to the disequilibrium in international markets, the price of steel is increasing at high levels. This implies that exports of steel could be profitable.

\section{Threats}

The steel industry is a very risky business; there are high price fluctuations that can lead to many losses for producers. Coming competition from India and China is a major threat for local steel producers. 


\section{CONCLUSION}

There are diverse market elements dealing with steel production in Egypt. Each element interprets the changes in the steel market from a particular point of view. However, there are essential commonalities. The analysis realized the monopoly position of Ezz-Dekhela at least as a dominant market power with short run price distortions and uncertain quantity distortions in the long run yet with superior operational and quality performance relative to other incumbents in the local industry. It is well understood that the case of steel in Egypt is unique because Ahmed Ezz is the head of the Industrial Committee in the National Democratic Party and is also a member of the Egyptian Parliament. Similar to Microsoft, market dominance can somehow be innovative.

However, it is forecasted that the Egyptian steel market will pick up for four reasons:

1. The high population growth rate and current demographic trends are expected to provide good future prospects for the steel industry in the long term.

2. Egypt is currently expanding its industrial sector and entering a new phase of industrial technology, accordingly demand for flat steel is expected to boost industry performance.

3. The mortgage law that was approved by the Parliament is expected to boost demand for housing in the construction sector and hence for steel.

4. The government of Egypt is currently implementing a 20 year ambitious plan ending 2017 in which major projects will be executed in the fields of infrastructure, tourism, and construction.

Furthermore, mergers and acquisitions of steel companies are common and increasing in the international market. Between 1995 and 1999 there were 213 mergers between steel companies, leading to 80 firms producing 70 percent of the world steel production. In this light, it is recommended that a major merge happen between the medium scale firms in Egypt in order to stand in competition with the dominant market player. Government intervention should pave the way for such a move.

\section{ACKNOWLEDGEMENTS}

Extensive research assistance provided by Farahnaz A. Hadi and Amir H. Wahib, undergraduate students at the Department of Economics of the American University in Cairo.

\section{REFERENCES}

1. Coal and Steel Facts, World Coal Institute, http://www.worldcoal.org/pages/content/index.asp?PageID=189.

2. The European Commission (EC), Industry Types-Basic Metals, Atlas Website, http://europa.eu.int.

3. Ghoneim, Ahmed, Competition Law and Competition Policy: What does Egypt Really Need?, Economic Research Forum (ERF), Ninth Annual Conference, 2002.

4. OECD Fact Report 2005: Economic, Environmental, and Social Statistics. OECD, http://hermia.sourceoecd.org.

5. Steel Flat Profile, Multi Commodity Exchange of India Ltd. http://www.mcxindia.com.

6. The Steel Making Industry, Primary Metals, http://www.p2pays.org/ref/01/text/00778/chapter2.htm.

\section{INTERVIEWEES}

Ahmed Refai for Steel Trading; Al Shady for Steel Trading; Alaa Raslan for Steel Trading; Basel El Hayawan, Secretariat, El Ghad Party and a construction engineer; Dr. Mohamed Ayesh, owner of International Steel Products Supply S.A.L.; Dr. Samir Makary, part time Professor of Economics at American University in Cairo; Egyptian Steel Company; Emad Shafee, private contractor; Magdy Fahmy, marketing manager at Beshay Steel; Mostafa Fayed, member of the Steel Syndicate; Ramy Abul Yazid; Other interviews with workers in the steel industry and inventory storages at El Hay El Tase' and El Asher in Nasr City, Egypt. 


\section{NOTES}

